\title{
Post Neo-Liberalism and the Humanities: What the Repressive State Ap- paratus Means for Universities
}

\author{
Emery J. Hyslop-Margison \& Hugh A. Leonard \\ University of New Brunswick
}

\begin{abstract}
In this article we explore how neo-liberal and post neo-liberal policies threaten the humanities in post-secondary education as a potential site of democratic dialogue and social transformation. We distinguish between neo-liberalism and post neo-liberalism on the basis of the latter's increased police suppression of democratic dissent. We are especially concerned with the impact of the repressive state apparatus on the critical public spaces traditionally provided by a humanities education. In response to this threat, we propose encouraging university faculty to assume a far more active political role in educating the general public on the relationship between the humanities and democratic societies.
\end{abstract}

\section{RÉSUMÉ}

Dans cet article, nous explorons comment les politiques néolibérales et post-néolibérales menacent l'enseignement postsecondaire des lettres et des sciences humaines comme lieu potentiel de dialogue démocratique et de transformation sociale. Nous faisons la distinction entre le néolibéralisme et le post-néolibéralisme selon l'augmentation de la suppression policière envers la dissidence démocratique du post-néolibéralisme. Nous nous inquiétons surtout de l'effet de l'appareil d'État répressif sur les espaces publics indispensables, fournis traditionnellement par l'enseignement des lettres et des sciences humaines. Pour contrer cette menace, nous proposons d'encourager les facultés universitaires à jouer un rôle politique beaucoup plus actif qu'actuellement afin d'enseigner au public général les relations existant entre les lettres et les sciences humaines et les sociétés démocratiques. 
When capitalism suffered major international crises during the 1970s, citizens of industrialized countries were informed through a range of ideological mechanisms that welfare state interventions in laissez-faire economics were entirely responsible. Rather than blaming the structural flaws and unavoidable contradictions in capitalism, corporate captains through their state intermediaries argued that general economic decline was caused by public interference in the market (Young, 1990). Corporate leaders and their government allies moved quickly to convince the public through mass media manipulation, or what Althusser (1971) described as the ideological state apparatus, that responsibility for the economic collapse rested with those who dared interfere with market logic (Moyers, 2011). It was a message widely accepted by the public, at least until mounting counter-evidence, in the form of renewed capitalist crisis and neo-liberal collapse, exposed the message as ideological myth.

The 2010 G20 protest response in Toronto and recent dismantling of the Occupy Wall Street movement illustrate the precarious state of contemporary democracy in the face of failed neo-liberal policies. The G2O consists of finance ministers and central banking governors from the world's major industrialized countries who meet on a regular basis to draft neo-liberal policies and imperatives. The Occupy Wall Street movement, as the name suggests, began in the fall of 2011 in New York City's Wall Street financial district. The Occupy Wall Street protests are directed against the widespread social injustice and economic inequality emerging from neo-liberal policies. The nearly one billion dollar security price tag for the combined G8 and G20 Canadian meetings, the arbitrary arrest and detention of independent journalists and a thousand other passive observers and protesters, and the point-blank firing of rubber bullets into the bodies of young women simply retreating from armoured, charging, baton-wielding police officers paint a troubling portrait of the contemporary democratic landscape (Canadian Broadcasting Corporation, 2010). Post neo-liberal capitalism and the rise of the repressive state apparatus (Althusser, 1971) have combined to launch concerted multi-pronged attacks on freedom of speech and assembly, including undercutting the public discursive university spaces that support democratic dialogue.

In this article we explore how neo-liberal and post neo-liberal policies threaten the humanities in post-secondary education as a potential site of democratic dialogue and social transformation. We distinguish between neo-liberalism and post neo-liberalism on the basis of the latter's increased police suppression of democratic dissent. We are especially concerned with the impact of the repressive state apparatus on the critical public spaces traditionally provided by a humanities education. In response to this threat, we propose encouraging university faculty to assume a far more active political role in educating the general public on the relationship between the humanities and democratic societies.

\section{THE EMERGENCE OF NEO-LIBERALISM}

In the late 1970 a major ideological shift in global economics emphasized unfettered free market policies and practices. Whereas liberals traditionally encouraged state involvement to soften the injurious blows of capitalism, neo-liberals, similar to their conservative counterparts, advocated instead for increased market dominance in all areas of public policy development. With the collapse of socialism in the 2oth century, neoliberalism became the dominant ideological force of economic and social policy develop- 
ment, and its policies achieved consensus as the only "natural" or "rational" approach to manage the economy (Kincheloe, Slattery, \& Steinberg, 2000).

Neo-liberalism offered a form of economic rationalism where market principles pervaded all areas of private and public discourse, including within the realm of public education. Education at all levels perpetuated the ahistorical and anti-democratic assumptions of neo-liberalism by advising students, either tacitly or explicitly, that their social role was limited to preparing for prevailing structural conditions. A preamble from a Canadian secondary school curriculum for a work preparatory program in the 1990 os reveals the typical ahistorical presentation of a socially constructed economic system:

The curriculum for Career and Personal Planning 8 to 12 has been designed to help students prepare to deal with a world of complex, on-going technological change, continuous challenge, expanding opportunities, and intricate social evolution. Learning opportunities that are relevant and experiential help students make informed choices, and take responsibility for their personal and career development. (BC Ministry of Education, 1995)

Freedom of choice, personal privacy, and other democratic ideals were not entirely dismissed by neo-liberal discourse, but were instead appropriated and tightly circumscribed by it. Democracy is acceptable within this context only to the extent that it does not interfere with market logic or, by extension, corporate authority. Hence, freedom and democracy are generally reduced by neo-liberalism to libertarian discursive mechanisms that permit financiers and the ruling elite to operate in ways that undercut the general welfare of society. There is a resulting conflation of democracy as a political practice with the freedom and autonomy of the market rather than with the freedom and autonomy of persons.

Perhaps the most characteristic feature of neo-liberalism is the systematic application of state authority, in a variety of anti-democratic policies and practices, to impose market imperatives on public policy development. Multilateral institutions such as the World Trade Organization (WTO), the International Monetary Fund (IMF), and the Organization for Economic Co-operation and Development (OECD) have all acted as vehicles to promote the policies of neo-liberal global capitalism. State and local political representatives routinely serve the interests of international capital, even at the expense of their own constituencies. In a moment of astonishing candour, for example, New Brunswick premier David Alward explained the cuts to education that immediately followed his election to office. In blatantly undemocratic terms, he emphasized the influence banks exert over governments that limits the actual decision-making capacity of elected officials: "There are great challenges," he admitted, "and if we don't start taking control of our finances now, in the future we won't have the chance to make the decisions. It will be the international banks making the decisions for us" (Berry, 2011, p. A1).The inclusion of market imperatives in public policy through neo-liberal imperatives has heavily influenced public education at all levels during the past three decades.

\section{NEO-LIBERALISM AND HIGHER EDUCATION}

The discourse that dominates current public education policy development suggests that neo-liberal logic is irrefutable. Neo-liberal principles are naturalized to students with- 
in industrialized nations in a variety of fashions, and schools and universities predictably become a primary state apparatus to deliver neo-liberal ideology. In public discourse, market logic is often expressed and validated as common sense. For example, Mike Harris, the former neo-liberal premier of Ontario, rose to power in 1995 by asking citizens to join him in what he described as a "common sense revolution" premised on significant cuts in taxes and government spending, elimination of barriers to job creation (including workers' compensation premiums and progressive labour legislation), reduction of the size of government, and, of course, major educational reform (Hyslop-Margison \& Sears, 2008). The common sense revolution was extended into public education with the expectation that subject matter be made "relevant" to economic concerns and curriculum be designed as a product of neo-liberal discourse. More generally, state administrative agencies aggressively sought to align education policies and programs with the human capital needs and ideological demands of neo-liberal capitalism.

Terry Eagleton has considered in some depth how ideology influences social thinking. He argued that making problematic and contestable assumptions part of common sense thinking is an extremely popular and effective ideological strategy (Eagleton, 1991). When something is deemed common sense to the general public, it becomes far more difficult to speak or act against it lest one is deemed as lacking in common sense. As part of his common sense revolution, Mike Harris, in a potential attack on the humanities, demanded data from college programs on the job placement rates of their graduating students (Canadian Union of Public Employees, 1998). This demand implied that non-instrumental subject areas that provided forums for potential social critique, areas such as the classics, history, philosophy, and political studies, might be eliminated through a lack of public funding.

Under past-premier Shawn Graham, the New Brunswick provincial government threatened to transform various universities into polytechnics with a focus entirely on technical skills and other instrumental learning outcomes. The proposed dismantling of the University of New Brunswick in Saint John and its transformation into a polytechnic was rationalized by a government-sponsored report on the basis of meeting short-term corporate labour market needs:

Saint John's emerging focus as an energy centre means that the polytechnic would be a natural extension of joint programming that would offer an enormous strategic advantage to the region and energy sectors. This would include technical, technological, and degree programs all related to energy, and offered not only in a single institution, but in an integrated fashion that facilitated synergy in research, teaching and learning. (Miner \& L'Ecuyer, 2007, p. 20)

Aside from championing fossil fuel exploitation at a time when our planet stands in grave peril because of $\mathrm{CO}_{2}$ emissions, the authors of this report obviated the democratic learning consistent with a university education focused on the humanities by identifying training objectives to satisfy the needs of industry as the primary goal of post-secondary education.

Concordia University in Montreal was recently marketed under the slogan real education for the real world (Hyslop-Margison \& Sears, 2008), a rhetorical and ideologically laden discursive ploy that effectively reduced learning to social efficiency precepts by implying there is some "real" social world beyond that shaped by human agency and decision making. Other universities, suffering from the precipitous decline of liberal education, and 
the decline of democratic and collegial governance principles, reveal this same shrinking sphere of public debate. Even where the humanities maintain some level of academic emphasis, they are increasingly refashioned to support neo-liberal objectives. For example, the English Department at the University of New Brunswick currently attempts to attract students to the subject area not on the basis of the rich educational experience associated with reading influential works of literature, but rather on the basis of the communication, critical thinking, and organizational skills students will presumably acquire for subsequent workplace application (University of New Brunswick, 2012). When this defence of the humanities is adopted, a concomitant signal is sent to students and to the general public that labour market preparation trumps all other post-secondary education objectives.

In the U.S. and Canada, an increasing number of research chairs are entirely corporate-sponsored with the attending obligation to direct their research agendas toward areas of inquiry that pay potential corporate dividends (Giroux, 2007). Universities dominated by a managerial-style administration view their relationship with students based on a business-model framework. Students are considered clients or customers of the university rather than members of a scholarly community with rights and responsibilities to help shape that community. For example, a recent article appearing in a University of Toronto publication extolled the new focus on students as "customers" who deserved good service as a brilliant policy not for delivering quality education but for nurturing long-term alumni loyalty and, of course, the financial contributions such loyalty generates (Hyslop-Margison \& Sears, 2008).

\section{POST NEO-LIBERALISM AND THE REPRESSIVE STATE APPARATUS}

As we argue above, neo-liberalism has been naturalized to students throughout public and post-secondary education as an unchangeable social reality rather than critiqued as an ideological movement imposed by hegemonic corporate interests on citizens of industrialized democratic societies. Outside the strictures of the global market, neo-liberal education conveys to students that very few meaningful choices are to be made. In a variety of ideologically manipulative ways, students are advised to prepare for an uncertain occupational future and are informed that these conditions stand outside the scope of their own political agency and possible democratic reform. However, the 2008 financial collapse and its aftermath dealt a serious blow to the ideological myth supporting the neo-liberal state. To sustain neo-liberal policies and the corporate benefits they generate, more aggressive tactics were required to counter increased citizen resistance. During periods of economic decline, states historically adopt more dictatorial, militarized approaches to implement unpopular economic reforms. The militarization of the neo-liberal state is evident in the increasing use of well-armed riot police to suppress every mode of resistance by citizens daring to assert their democratic right to advocate for structural change (Graham, 2011).

In many cases, the law is continually amended to allow the police to "discipline" people, restrict democratic rights of association, and make it virtually impossible for citizens to voice their collective concern in any public forum. For example, the G2o Summit in Toronto precipitated the passing of secret legislation that afforded the police sweeping arrest and detainment powers. The province of Ontario quietly passed a law that permitted police to arrest people wandering near the G20 security zone who refused to identify 
themselves or agree to an arbitrary police search of person and property. The legislation was passed under Ontario's Public Works Protection Act and, consequently, was not subject to inter-party debate in the provincial legislature. According to a provincial spokesperson, the cabinet action came in response to an "extraordinary request" by Toronto police chief Bill Blair, who demanded sweeping police powers shortly after learning the G2O was coming to Toronto. The clandestinely passed law empowered "guards" appointed under the act to arrest anyone who came within five metres of the security zone. The legislation resulted in shocking abuses of police power, including unnecessary acts of violence and oppression against citizens simply exercising their democratic rights of assembly and public protest (Yang, 2010, n.p.).

Another example of an undemocratic law, this one supported by the U.S. Supreme Court's 5-4 decision in Citizens United v. Federal Election Commission (2010), permits corporations, as individuals whose free speech is protected under the First Amendment, to funnel unlimited funds into political campaigns. "Starting today," wrote dissenting justice J. Stevens, "corporations with large war chests to deploy on electioneering may find democratically elected bodies becoming much more attuned to their interests" (p. 65). He concluded scornfully, "While American democracy is imperfect, few outside the majority of this Court would have thought its flaws included a dearth of corporate money in politics" (p. 90). Unfortunately, the few outside the court's majority who do hold this thought constitute, in the rhetoric of the Occupy Wall Street movement, the 1\% of American society that controls 40\% of the nation's wealth (Stiglitz, 2011, n.p.). Journalist Bill Moyers linked this added advantage of the corporate elite to the discouragement of the real majority whose "hearts no longer burn with the conviction that they are part of the deal" (p. 14). When the neo-liberal state can no longer delude citizens through the ideological state apparatus (ISA) that includes media manipulation and the general control of ideas, violence and the repressive state apparatus (RSA) become increasingly necessary to maintain the unjust socio-economic order.

In his analysis of capitalist society, Althusser (1971) distinguished between the ideological state apparatus (ISA) that emerges from base/superstructure interaction and the repressive state apparatus (RSA). The ISA occurs in the form of distinct and specialized institutions designed to manipulate public opinion in a manner conducive to protecting hegemonic interests. These institutions typically include the religious ISA (the system of the different churches), the educational system (the system of the public and private schools, including universities), the family, the legal system, the political ISA (the political system, including the different parties), trade unions, the communications and/or media systems (press, radio, television, and so on), and cultural preoccupations (literature, the arts, sports, and so on). The RSA includes the type of police action that occurred during the 2010 Toronto G20 Summit designed to protect ruling class interests by forcefully suppressing popular dissent. The present militarization of the capitalist state within Canada, then, reflects a shift from the ISA to the RSA with potentially profound consequences for post-secondary education.

Post neo-liberal capitalism, a term we employ to capture current neo-liberal economic decline, routinely applies the RSA because the more subtle tools of ideological manipulation have fallen into disrepute, thereby losing some of their force and credibility. The common sense myth supporting neo-liberalism for all intents and purposes has been 
widely exposed. Whereas the ISA functions by ideology, the RSA primarily functions by violence, intimidation, and physical oppression, although it retains and employs the more subtle tools of ideological manipulation. According to Althusser (1971), it is necessary for capitalist states to function primarily through the ideological state apparatuses because no state can survive indefinitely through continued violence and oppression. Post neoliberal states such as Canada therefore can be expected to pursue a double functioning both by police repression and by continued ideological manipulation. When the ISA fails to suppress public dissent, as it did among those attending the G2O in Toronto or with the Occupy Wall Street movement, the RSA stands ready to invoke supplementary action. Because the corporate class, or hegemony, controls state power, and therefore has at its disposal the state-controlled police, it will use the RSA when ideological means to suppress dissent fail.

We do not suggest that neo-liberal capitalism never employed aggressive and violent tools of capitalist oppression. Quite to the contrary, it undeniably pursued a considerable level of multi-pronged and sustained violence against citizens. Whether it was the widespread elimination of social programs, the paucity of decent employment opportunities, the dramatic rise in poverty, or the more overt violence during the 1997 World Trade Organization meetings in Seattle and the 2008 G8 Summit in Quebec City, neo-liberalism was willing to employ oppressive methods when required. Nevertheless, it was a capitalism still basking in the delight of socialist collapse and correspondingly portrayed and widely accepted as the best of all possible worlds.

Unlike post neo-liberalism, neo-liberalism was primarily sustained by common sense ideology and through the false promise to deliver wealth and happiness to those who, as Canadian prime minister Harper stated with no intended irony, "play by the rules" (Conservative Party of Canada, 2012, n.p.). However, the "promise" of neo-liberal capitalism completely collapsed alongside the housing bubble and toxic security investments made by greedy Wall Street financiers, who, as demonstrated by their actions, lacked concern for rules or, more importantly, general community welfare. So, what does the shift toward the increased presence of the RSA potentially mean for Canadian post-secondary education in general and the humanities in particular?

\section{POST NEO-LIBERALISM AND THE HUMANITIES}

We believe the importance of public discursive spaces to democratic society and the current threats posed to these spaces cannot be overstated. Habermas (1996) suggested that neo-liberalism has led to widespread destruction of the life world. The life world for Habermas consisted of those fundamental human experiences, spaces, and interactions that generate a sense of inner peace or individual well-being, and also provide the necessary community space for meaningful democratic discussion. The complete destruction of these public spaces in post-secondary education becomes necessary in post neo-liberalism because the critical forum they provide constitutes a genuine threat to the unjust economic structure. When higher education programs such as the humanities, which afford students as future citizens the knowledge and the opportunity to engage in critical discussions, are eliminated and/or marginalized, this development constitutes an attack on the fundamental principles of democracy. 
In Not for Profit: Why Democracy Needs the Humanities, Martha Nussbaum (2010) compellingly argued for the importance of the humanities to democratic societies. She pointed out that the erosion of traditional ideas connecting higher education with democratic citizenship and personal character have been widely replaced by an instrumental conception of post-secondary learning exclusively focused on short-term economic gain. According to Nussbaum, the consequential threat to democracy is significant: "If this trend continues, nations all over the world will soon be producing generations of useful, docile, technically trained machines, rather than complete citizens who can think for themselves, criticise tradition, and understand the significance of another person's sufferings and achievements" (p. 2).

Nussbaum (2010) described contemporary education as suffering from a worldwide democratic crisis, and explained how democracy relies heavily on the values embedded in students by the arts and humanities. Democratic societies use the humanities to reveal, understand, and question their own values and desires, their fears and dreams, and to expose internal tensions and contradictions. But the value of the arts, in this respect, is contingent on the ability to think, judge, and criticize for oneself, characteristics that Nussbaum argued are consistent with a humanities education. The citizen educated in the art of following "argument rather than numbers," Nussbaum observed, "is a good person for a democracy to have, the sort of person who would stand up against the pressure to say something false or hasty" (p. 51).

In The Educated Imagination, Canadian scholar and renowned literary critic Northrop Frye (2006) similarly argued that art and literature manipulate our emotions toward moral considerations with tremendous social implications:

Literature keeps presenting the most vicious things to us as entertainment, but what it appeals to is not any pleasure in these things, but the exhilaration of standing apart from them and being able to see them for what they are because they aren't really happening. The more exposed we are to this, the less likely we are to find an unthinking pleasure in cruel or evil things. As the eighteenth-century said in a fine mouth-filling phrase, literature refines our sensibilities. (p. 472)

In response to the perennial demand for defenders of the humanities to state the practical relevance of these disciplines, Frye mused:

One of the most obvious uses, I think, is its encouragement of tolerance. In the imagination our own beliefs are also only possibilities, but we can also see the possibilities in the beliefs of others. Bigots and fanatics seldom have any use for the arts, because they're so preoccupied with their beliefs and actions that they can't see them as also possibilities. It's possible to go to the other extreme, to be a dilettante so bemused by possibilities that one has no convictions or power to act at all. But such people are much less common than bigots, and in our world much less dangerous. (p. 464)

Within neo-liberal capitalism, the goals of corporations were routinely adopted by higher education in the near absence of any concerted or meaningful faculty response. Among university administrators, there is widespread complicity with post neo-liberal education 
values. For example, the University of Toronto recently sought to close a centre devoted to Northrop Frye. The University of Toronto's Centre for Ethics, the newly created Centre for Diaspora and Transnational Studies, the Centre for International Studies, and five language departments are also scheduled for closure. The university will eventually no longer grant graduate degrees in comparative literature, and no additional faculty will be hired in that subject area (Pitas, 2010). Of course, the situation at the University of Toronto, although high profile, is far from unique among Canadian post-secondary institutions.

At the University of New Brunswick, most graduate programs in the humanities have been reduced to mere skeleton status. In their place, there is a continual rise in so-called university centres, staffed primarily by non-academic staff and directors focused on such issues as research grant procurement, the development of online courses, teaching faculty how to teach, and, of course, implementing the omnipresent accountability measures designed to preoccupy and control faculty. The university has created an administrative bureaucracy in charge of virtually every academic matter. Compliant faculty, often more committed to short-term self-interest than long-term educational values, spend increasing amounts of their time responding to the needs of the administrative bureaucracy.

Under post neo-liberalism, we should expect to witness continued and more forceful challenges to universities as potential sites for public democratic critique of structural design. One prevailing response to these threats attempts to justify the humanities on the basis of human capital objectives such as evidenced by the English Department at the University of New Brunswick. We are skeptical that this type of compliance with post neo-liberal dictates protects the humanities as meaningful democratic forums. Indeed, emboldened by increased state implementation of the RSA, corporate captains, government officials, and allied university administrators are likely to launch even more brazen and concerted attacks against potentially counter-hegemonic disciplines. There are various warning signs to consider.

The organization of presidents of Canadian universities recently issued a revised and unanimously supported statement on academic freedom that undercut many of the advances achieved by Canadian faculty over the past century (Canadian Association of University Teachers [CAUT], 2011a). The Association of Universities and Colleges of Canada (AUCC) statement removes the right of faculty to publicly criticize their institution and fails to recognize that academic freedom must be respected across teaching, research, and service. In their response to the AUCC statement, CAUT representatives James Turk and Wayne Peters correctly argued, "With the growing pressures on universities to compromise their defense of academic freedom in the quest for financial support, we need a more expansive notion of academic freedom, not a more restrictive one" (CAUT, 2011a, p. A1).

Rather than simply employing neo-liberal ideology to limit Canadian universities as possible sites for democratic dissent, post neo-liberal attacks tend to be far more aggressive and explicit in nature. At the University of New Brunswick, for example, the institution's faculty association recently wrote an open letter to the university president condemning the administration's attempt to prevent union organizing activities on campus by incorrectly deeming them "illegal" (CAUT, 2011b, A9). Complicity and acquiescence are unlikely to restore universities as sites for democratic discourse, and we must therefore consider more forceful measures, as described below, to protect the humanities from post neo-liberal assault. 


\section{UNIVERSITY FACULTY AS PUBLIC INTELLECTUALS}

We have argued above that democracies are only authentic to the extent their citizens are offered genuine political options and provided with public discursive spaces, such as those afforded by the humanities, where these issues may be explored and debated. The democratic responsibility of university faculty to discuss alternative social visions and critique prevailing social and economic design is currently obviated by corporate influence, complicit governments, and a university managerial class comprised largely of unrepentant neo-liberal sycophants and administrators. The idea among academics that university faculty should fulfill the role of a public intellectual has virtually disappeared. In this final section of the article, then, we suggest that the idea of university faculty as public intellectuals should be strengthened to redress the post neo-liberal siege that threatens the humanities and the democratic discursive spaces they provide.

Previously mentioned scholar Terry Eagleton (2008) lamented his own preoccupation with academic success rather than choosing to confront neo-liberal political challenges as a public intellectual. He mocked the experience by sardonically recounting the mostly mundane nature of academic work: "I spent a number of lonely evenings embroiled in the revolutionary struggle to turn commas into colons, [and] introduce some elementary paragraphing into a seamless text. We had to fight hard to find the book a publisher, but were finally successful" (p. 351). Russell Jacoby (2000) mourned the departure of contemporary academics away from the Enlightenment ideals committed to moral and social progress. In his view, many academics within the current technocratic university environment instead wallow in a "convenient cynicism" that "dismisses utopian visionaries as dangerous cranks" (p.80). The unfortunate outcome of this cynicism is the loss of hope that "inequality and suffering are not inherent to the human condition, [and] that a more humane society is possible" (Jacoby, 2000, p. 80).Within the current morally skeptical academic milieu dominated by market-driven technical rationality and postmodern cynicism, Jacoby (1999) observed, "Radicals have lost their bite and liberals their backbone" (p. xii). Obviously, as academics we ought to take our scholarship seriously, but as Eagleton and Jacoby suggested, we should not see our scholarship as simply an end in itself. We should also ask ourselves how our work more generally, both inside and outside the university, influences society.

We also appreciate that the journey to become a public intellectual is not a decision of pure self-determination. Obviously, most of us will not attain the status of Noam Chomsky, Christopher Hitchens, or Cornel West, but we can take important messages about our disciplines and institutions outside the strictures of the university. The relationship between the humanities and democratic societies is precisely the type of academic issue that requires clearer explanation and wider dissemination. Faculty who genuinely care about the issue can no longer afford to limit the discussion to faculty council meetings, academic journals, and university forums, or to market the humanities on the basis of their possible contribution to post neo-liberal objectives. The message must be delivered directly into the public and political realms by faculty through media discussions, popular mainstream publications, public appearances, and political debates at municipal, provincial, and federal levels.

\section{CONCLUSION}

The post neo-liberal period poses tremendous intellectual and political challenges to prevent Canadian democratic society from drifting toward a quasi-fascist state where pub- 
lic dissent is completely suppressed. The humanities have an indispensable role to play in ensuring citizens are adequately prepared with the knowledge, understanding, and critical spirit of inquiry to confront these challenges successfully. The current trend in the humanities to justify programs on the basis on their contribution to post neo-liberal objectives devalues the traditional intellectual and democratic role played by the disciplines.

As faculty we must be far more public in our defence of the university sector as offering society something more than simply another corporate training facility. This stance requires taking our arguments supporting the relationship between the humanities and democracy outside the university to educate aspiring politicians and the general public on the matter. There are obvious personal and professional political risks in challenging the post neo-liberal attack on public discursive spaces inside and outside the university. Yet, our social responsibility as academics must move us beyond narrow career considerations and promote a long-term vision on the interaction between academic work and the collective welfare of society. The stakes are high in this struggle because its success will determine not merely the future of the humanities, but quite possibly the future of Canadian democratic society as well.*

\section{REFERENCES}

Althusser, L. (1971). Lenin and philosophy and other essays. New York, NY: Monthly Review Press.

BC Ministry of Education. (1995). Career and personal planning grades 11-12. Victoria, BC: Author.

Berry, S. (2011, May 30). Alward gets his knuckles rapped by teachers: Education premier faces French educators upset with recent budget cuts. The Daily Gleaner, MA1.

Canadian Association of University Teachers (CAUT). (2011a). CAUT challenges AUCC attempt to downsize academic freedom. CAUT Bulletin, 58(10), A1. Canadian Association of University Teachers (CAUT). (2011b). AUNBT alleges interference in union drive. CAUT Bulletin, 58(10), A9.

Canadian Broadcasting Corporation. (2010, July 24). Police shot rubber bullets, woman says. Retrieved from http://www.cbc.ca/news/canada/story/2010/07/24/g20rubber-bullets.html

Canadian Union of Public Employees. (1998). The attack on our schools: Students and staff fight back. Retrieved from http://cupe.ca/EducationK12/BE4617

Citizens United v. Federal Election Commission, 8 U.S. 205 (2010). Retrieved from http://www.supremecourt.gov/opinions/o9pdf/08-205.pdfConservative Party of Canada. (2012). Here for Canada. Retrieved from http://www.conservative.ca/leader/ stephen_harper/a_leader_of_competence_and_vision?language_id =0

Eagleton, T. (1991). Ideology. London, England: Verso.

Eagleton, T. (2008). Comrades and colons. Antipode, 4O(3), 351-356.

Frye, N. (2006).The educated imagination and other writings on critical theory: 1933-1963. Toronto, ON: University of Toronto Press.

Giroux, H. (2007). The university in chains: Confronting the military industrial complex. Boulder, CO: Paradigm. 
Graham, S. (2011). Cities under siege: The military urbanism. London, England: Verso.

Habermas, J. (1996). Between facts and norms: Contributions to a discourse theory of law and democracy. Cambridge, MA: MIT Press.

Hyslop-Margison, E. J., \& Sears, A. (2008). The neo-liberal assault on democratic learning. UCFV Research, 2(1), 28-38.

Jacoby, R. (1999). The end of utopia: Politics and culture in an age of apathy. New York, NY: Basic Books.

Jacoby, R. (2000, December). A brave new world: Looking forward to a nineteenthcentury utopia. Harper's Magazine.

Kincheloe, J., Slattery, P., \& Steinberg, S. (2000). Contextualizing teaching. New York, NY: Longman Press.

Miner, R., \& L'Ecuyer, J. (2007). Advantage New Brunswick: A province reaches to fulfill its destiny. Fredericton, NB: Province of New Brunswick.

Moyers, B. (2011). How Wall Street occupied America. Nation, 293(21), 11-14.

Nussbaum, M. (2010). Not for profit: Why democracy needs the humanities. Princeton, NJ: Princeton University Press.

Pitas, J. M. (2010, July 12). University of Toronto plan decimates languages, humanities programs. Retrieved from http://rabble.ca/news/2010/o7/university-toronto-plandecimates-languages-humanities-programs

Stiglitz, J. (2011. May). Of the 1\%, by the 1\%, for the 1\%. Vanity Fair. Retrieved from http://www.vanityfair.com/society/features/2011/05/top-one-percent-201105

University of New Brunswick. (2012). Why study English? Retrieved from http:// www.unb.ca/fredericton/arts/departments/english/index.html

Yang, J. (2010, June 25).G20 law gives police sweeping power to arrest people. The Toronto Star. Retrieved from http://www.thestar.com/news/gta/article/828367--g20law-give-police-sweeping-powers-to-arrest-peopleYoung, R. (1990). A critical theory of education: Habermas and our children's future. New York, NY: Teachers College Press.

\section{CONTACT INFORMATION}

Emery J. Hyslop-Margison

Faculty of Education

University of New Brunswick

P.O. Box 4400

Fredericton NB E3B 5A3 Canada

ehyslopm@unb.ca

Emery J. Hyslop-Margison is a Professor and Research Coordinator in the Faculty of Education at the University of New Brunswick.

Hugh A. Leonard is a PhD student in Educational Studies in the Faculty of Education at the University of New Brunswick. 